\title{
PENGARUH MEDIA RICHNESS TERHADAP USER TRUST DAN PERSEPSI CORPORATE SOCIAL RESPONSIBILITY:
}

\author{
Ayu Noorida Soerono \\ ayu soerono@yahoo.com \\ Universitas Sultan Ageng Tirtayasa
}

\author{
Mazda Eko Sri Tjahjono \\ mazda tjahjono@yahoo.com \\ Universitas Sultan Ageng Tirtayasa
}

\section{Hady Sutjipto \\ hadis@gmail.com \\ Universitas Sultan Ageng Tirtayasa}

\begin{abstract}
ABSTRAK
Studi ini meneliti pengaruh media richnerss terhadap user trust dan persepsi corporate social responsibility dengan sensitivitas lingkungan industri sebagai variabel moderating. Populasi dalam penelitian ini adalah manajer pada perusahaan manufaktur di provinsi Banten yang listing di Bursa Efek Indonesia (BEI). Jumlah perusahaan manufaktur di provinsi Banten sebanyak 45 perusahaan manufaktur. Teknik penentuan sampel dalam penelitian ini dengan menggunakan teknik purposive sampling. Metode purposive samping merupakan metode pemilihan sampel yang seseuai dengan penelitian ini yaitu; 1) Perusahaan manufaktur di provinsi Banten yang listing di BEI, 2) Responden dalam penelitian ini adalah manajer keuangan, manajer produksi, manajer sumber daya manusia, manajer pemasaran. Jumlah responden dalam penelitian ini adalah sebanyak 180 responden. Penelitian ini menggunakan simple regression analysis sebagai alat analisis regresi sederhana dan menggunakan nilai selisih mutlak dengan menggunakan software Statistical Package for Social Science(SPSS). Hasil penelitian ini adalah menunjukkan bahwa adanya pengaruh positif antara media richness terhadap user trust, sensivitas lingkungan industri tidak memoderasi hubungan antara media richness dengan user trust, pengaruh positif namun tidak signifikan media richness terhadap persespi corporate social responsibility.
\end{abstract}

Kata Kunci: Corporate social responsibility, User trust, Media richness theory, dan Informasi media.

\section{Latar Belakang Penelitian}

\section{PENDAHULUAN}

Perubahan dalam lingkungan bisnis terjadi sangat cepat yang membuat banyak perusahaan menggunakan website dalam melaporkan informasi keuangan maupun informasi non keuangannya. Website memudahkan pengungkapan informasi yang lebih tepat waktu dibandingkan dengan pengungkapan informasi dengan cara tradisional atau dengan menggunakan kertas (Koreto, 1997 dalam Cho et al, 2009). Selain itu, website memiliki jangka waktu tidak terbatas yang dapat membuat perusahaan menghemat biaya dalam 
melakukan penyajian pengungkapan informasi keuangan maupun non keuangannya. Informasi merupakan kebutuhan yang mendasar bagi investor dan calon investor dalam pengambilan keputusan. Salah satu informasi yang diminta untuk diungkapkan adalah informasi tentang tanggung jawab sosial perusahaan.

Tanggung jawab sosial perusahaan merupakan ketersediaan informasi keuangan dan non-keuangan berkaitan dengan interaksi organisasi dengan lingkungan fisik dan lingkungan sosialnya, yang dapat dibuat dalam laporan tahunan perusahaan atau laporan sosial terpisah (Sembiring, 2005). Aktivitas tanggung jawab sosial perusahaan perlu diinformasikan karena dapat mempengaruhi perilaku para pemimpin sehubungan dengan target organisasi (Harmoni, 2010). Oleh karena itu, website merupakan sarana potensial bagi perusahaan dalam pengungkapan informasi sebagai transparansi dan pertanggungjawaban mengenai isu lingkungan (Jones et al, 1998 dalam Cho et al, 2009).

Dalam hal ini terdapat dua motivasi yang mendasari perusahaaan dalam mengungkapkan aktivitas CSRnya. Dua motivasi tersebut didasarkan pada pada teori stakeholder dan teori legitimasi. Dalam teori stakeholder disebutkan bahwa perusahaan akan memilih stakeholder yang dianggap penting dan mengambil tindakan yang dapat menghasilkan hubungan harmonis antara perusahaan dan stakeholdernya (Ghozali dan Chariri, 2007 dalam Munif, 2010). Oleh karena itu, perusahaan akan mempertimbangkan aktivitas serta pengungkapan CSR ini dengan harapan agar mempunyai hubungan yang baik dengan para stakeholder perusahaan.

Dalam teori legitimasi juga dikemukakan motivasi lainnya. Dalam teori tersebut disebutkan bahwa perusahaan menunjukkan berbagai aktivitas sosial perusahaan agar perusahaan memperoleh penerimaan masyarakat akan tujuan perusahaan yang pada akhirnya akan menjamin kelangsungan hidup perusahaan (Brown and Deegan, 1998; Guthrie and Parker, 1989; Deegan, 2002; dikutip dari Reverte, 2008). Oleh karena itu, perusahaan mempertimbangkan aktivitas serta pengungkapan CSR dengan harapan memperoleh legitimasi dari publik. Perusahaan menggunakan pengungkapan ini untuk membenarkan atau melegitimasi aktivitas perusahaan di mata masyarakat. Hal ini dikarenakan, pengungkapan aktivitas CSR akan menunjukkan tingkat kepatuhan suatu perusahaan seperti kepatuhan terhadap norma-norma yang berlaku, serta harapan-harapan publik kepada perusahaaan tersebut (Branco dan Rodrigues, 2008 dalam Munif, 2010).

Dalam penelitian sebelumnya ada pendapat bahwa media richness dalam penyajian informasi dapat memberikan pengaruh yang kuat dalam pengkomunikasiannya dibandingkan dengan penyajian informasi dalam bentuk dokumen kertas (Davidson, 2007 dalam Cho et al, 2009), dan menggunakan foto atau bentuk visual komunikasi potensial lainnya yang dapat membiaskan pengguna (Preston et al, 1996 dalam Cho et al, 2009). Karena komunikasi dua arah dalam permasalahan CSR sangat penting untuk menciptakan rasa hormat dan penghargaan dari para stakeholder.

Sensitivitas industri dapat diartikan sebagai seberapa besar tingkat industri tersebut bersinggungan langsung dengan konsumen dan kepentingan luas lainnya. Oleh karena itu, pada umumnya perusahaan yang mempunyai sensitivitas industri yang tinggi terhadap lingkungannya akan memperoleh perhatian yang tinggi mengenai lingkungan tersebut dibandingkan dengan perusahaan-perusahaan yang mempunyai sensitivitas industri yang lebih rendah terhadap lingkungannya. Hal ini dikarenakan perusahaan tersebut mempunyai 
dampak potensi yang lebih tinggi dalam mempengaruhi kondisi serta keberadaan lingkungan tersebut (Branco dan Rodrigues, 2008 dalam Munif, 2010). Pada beberapa penelitian yang telah dilakukan menunjukkan bahwa perusahaan-perusahaan yang proses manufaktur perusahaan mempunyai pengaruh negatif pada lingkungan, maka pengungkapan dan pelaporan akan lebih informative dibandingkan dari industri lainnya (Reverte, 2008).

Dalam penelitian sebelumnya ditegaskan kembali oleh penelitian Cho et al. (2009) yang tidak berfokus pada peningkatan tanggung jawab sosial namun kepada kualitas penggunaan dari media richness yang dapat menyajikan kebenaran dari pengungkapan dan dapat digunakan untuk memperjelas keterangan dari pengungkapan tanggung jawab sosial. Dalam penelitian Lodhia (2004) berpendapat bahwa kemampuan website dalam penggunaan media richness pada penyajian informasi yang menggunakan banyak isyarat seperti kalimat, foto, dan video dapat meningkatkan pengungkapan laporan tanggung jawab sosial perusahaan.

Sedangkan fenomena yang dapat ditemukan sehubungan dengan penelitian ini adalah pentingnya komunikasi tentang tanggung jawab sosial perusahaan atau corporate social responsibility (CSR). Aktivitas CSR perusahaan perlu di komunikasikan karena dapat mempengaruhi perilaku para pemimpin sehubungan dengan target organisasi dan karena kemajuan teknologi dan komunikasi itu sendiri (misalnya website) dalam beberapa tahun ini. Dan pada saat ini publik tidak akan mudah percaya pada perusahaan yang melebih-lebihkan aktivitas sosialnya, sehingga pendapat publik juga dapat menjadi penentu berhasil atau tidaknya kegiatan CSR suatu perusahaan (Harmoni, Ati., 2010).

Penelitian mengenai penyajian pengungkapan informasi tanggung jawab sosial dan lingkungan melalui website termasuk jarang dilakukan dalam penelitian-penelitian CSR. Beberapa penelitian mengenai situs CSR sebelumnya membandingkan tema dari masingmasing negara (Chapple dan Moon, 2005 dalam Rahmawani dam Dwi Hartanti, 2010). Dan penelitian ini dilakukan untuk mengetahui pengaruh dari media richness terhadap tingkat kepercayaan bagi pemangku kepentingan. Penelitian ini juga untuk mengetahui bagaimana perusahaan dari berbagai bidang (lingkungan sensitif atau tidak) sebagai moderating yang saling berhubungan. Menurut penelitian yang dilakukan oleh Cho et al. (2009) penyajian pengungkapan tanggung jawab sosial dan lingkungan berpengaruh positif terhadap tingkat kepercayaan pengguna dan persepsi dari pengungkapan tanggung jawab sosial dan lingkungan.

\section{TINJAUAN PUSTAKA}

\section{Teori Legitimasi}

Teori legitimasi didasarkan pada pengertian kontrak sosial yang diimplikasikan antara institusi sosial dan masyarakat. Legitimasi masyarakat merupakan faktor stategis bagi perusahaan dalam rangka mengembangkan perusahaan ke depan. Hal itu dapat dijadikan sebagai wahana untuk mengkonstruksikan strategi perusahaan, terutama terkait dengan upaya memposisikan diri ditengah lingkungan masyarakat yang semakin maju (Nor Hadi, dalam Elvinaro dan Dindin. 2011). Legitimasi organisasi dapat dilihat sebagai sesuatu yang diberikan masyarakat kepada perusahaan dan sesuatu yang diinginkan atau dicari perusahaan dari masyarakat. Maka dari itu, legitimasi merupakan manfaat atau sumber daya potensial 
bagi perusahaan untuk bertahan hidup (going concern) (O’Donovan, dalam Elvinaro dan Dindin. 2011).

Legitimasi merupakan suatu sistem yang mengedepankan keberpihakan kepada masyarakat (Grey. et al, dalam Elvinaro dan Dindin. 2011). Teori legitimasi dianalisis dari sebuah perspektif manajerial yang difokuskan pada berbagai strategi manajer yang dapat memilih legitimasi yang diharapkan, (Deegan, et al. dan Pattern, dalam Elvinaro dan Dindin. 2011).

Menurut Wartick dan Mahon, dalam Elvinaro dan Dindin. (2011),. Legitimacy gap (incongruence) dapat terjadi karena beberapa faktor:

a. Ada perubahan dalam kinerja perusahaan, tetapi harapan masyarakat terhadap kinerja perusahaan tidak berubah.

b. Kinerja perusahaan tidak berubah, tetapi harapan masyarakt terhadap kinerja perusahaan sudah berubah.

c. Kinerja perusahaan dan harapan masyarakat berubah ke arah yang berbeda atau ke arah yang sama tetapi waktunya berbeda.

Aktivitas organisasi perusahaan hendaknya sesuai dengan nilai sosial lingkungannya. Terdapat dua dimensi agar perusahaan memperoleh dukungan legitimasi: Pertama, aktivitas organisasi perusahaan harus sesuai (congruence) dengan sistem nilai masyarakat. Kedua, pelaporan aktivitas perusahaan hendaknya mencerminkan nilai-nilai sosial (Dowling dan Pfeffer, dalam Elvinaro dan Dindin. 2011).

Upaya yang perlu dilakukan oleh perusahaan dalam rangka mengelola legitimasi agar efektif : (1) Melakukan identifikasi dan komunikasi atau dialog dengan publik, (2) Melakukan komunikasi atau dialog tentang masalah nilai sosial kemasyarakatan dan lingkungan, serta membangun persepsi tentang perusahaan, (3) Melakukan strategi legitimasi dan pengungkapan terkait CSR (Pattern, dalam Elvinaro dan Dindin, 2011).

\section{Teori Stakeholder}

Stakeholder merupakan semua pihak, internal maupun eksternal, yang dapat mempengaruhi ataupun dipengaruhi oleh perusahaan baik secara langsung maupun tidak langsung. Stakeholder is a group or an individual who can effect, or be affected by, the success or failure of an organization (Luk, Yau.Tse, Alan, Sin, Leo, dan Raymond, dalam Elvinaro dan Dindin, 2011).

Stakeholder adalah individu-individu dan kelompok-kelompok yang memiliki legitimasi untuk menuntut kepada organisasi agar bisa berpartisipasi dalam pengambilan keputusan, karena merekan dianggap dipengaruhi oleh praktik, kebijakan dan tindakan organisasi (Hummels, dalam Elvinaro dan Dindin, 2011). Dari definisi tersebut dapat diartikan bahwa perusahaan hendaknya memperhatikan stakeholder, karena mereka adalah pihak yang mempengaruhi dan dipengaruhi baik secara langsung maupun tidak langsung atas aktivitas dan kebijakan yang diambil perusahaan. Jika perusahaan tidak memperhatikan stakeholder, bukan tidak mungkin akan menuai protes dan mengeliminasi stakeholder (Nor Hadi, dalam Elvinaro dan Dindin, 2011).

Asumsi Stakeholder Theory: (1) perusahaan memiliki hubungan dengan banyak kelompok-kelompok konstituen (stakeholder) yang mempengaruhi dan dipengaruhi oleh keputusan perusahaan, (2) teori ini ditekankan pada sifat alami hubungan dalam proses dan 
keluaran bagi perusahaan dan stakehodernya, (3) kepentingan semua legitimasi stakeholder memiliki nilai secara hakiki, dan tidak membentuk kepentingan yang didominasi satu sama lain, (4) teori ini memfokuskan pada pengambilan keputusan manajerial (Thomas dan Andrew, dalam Elvinaro dan Dindin, 2011).

Berdasarkan asumsi stakeholder theory, maka perusahaan tidak dapat melepaskan diri dari lingkungan sosial. Perusahaan perlu menjaga legitimasi stakeholder serta mendudukannya dalam kerangka kebijakan dan pengambilan keputusan, sehingga dapat mendukung pencapaian tujuan perusahaan, yaitu stabilitas usaha dan jaminan going concern (Adam, dalam Elvinaro dan Dindin, 2011).

\section{Media Richness Theory (MRT)}

Media Richness Theory (MRT) adalah teori yang banyak digunakan dalam pemilihan media komunikasi. MRT pertama kali dikemukakan oleh Daft and Lengel (1986) yang menyatakan bahwa kegunaan suatu media ditentukan oleh "kekayaan”-nya (richness). MRT ini berkenaan dengan penentuan media komunikasi yang paling tepat untuk menghadapi ketidakpastian dan ketidakjelasan dari informasi (Daft and Lengel, 1986). Media yang "kaya” (yaitu tatap muka langsung dan telepon) dianggap lebih tepat untuk mengatasi situasi yang tidak jelas yang memungkinkan terjadinya multiinterpretasi terhadap informasi yang tersedia, sementara media yang "miskin" (yaitu dokumen tertulis atau komunikasi melalui media komputer) tepat digunakan untuk mengurangi ketidakpastian dimana informasi sangat terbatas (Harmoni, 2010). Daft and Lengel (1986) mengusulkan empat kriteria untuk menilai kekayaan media yaitu immediacy, multiple cues, languange variety, dan personal source.

Kesegeraan (immediacy) merupakan kemampuan media untuk menyediakan informasi secara berkala dan memungkinkan umpan balik secara tepat. Kriteria ini penting bagi proses komunikasi karena terjadinya penundaan dapat menyebabkan isu penting menjadi tidak penting lagi. Keseragaman isyarat (multiple cues) mengacu pada kemampuan untuk mengkomunikasikan pesan melalui pendekatan yang berbeda, seperti tubuh, bahasa, suara, dan intonasi. Variasi bahasa (languange variety) menunjukkan kemampuan penggunaan kata yang berbeda untuk meningkatkan pemahaman, yaitu pada variasi cara dalam menyampaikan ide dan konsep melalui simbol bahasa. Sedangkan sumber personal (personal source) merupakan kemampuan untuk menunjukkan perasaan dan emosi (Harmoni, 2010).

Dalam potensi teknologi komunikasi modern yang semakin berkembang, Lodhia (2004) berpendapat bahwa ada penambahan kriteria dalam menilai kekayaan media ini, yaitu multiple addressibility, externally recordable, computer processable memory, dan concurreny. Keragaman penerima (multiple addressibility) merupakan kemampuan untuk menyampaikan pesan secara simultan kepada banyak pengguna. Kriteria perekaman eksternal (externally recordable) berhubungan dengan kemampuan media untuk menyediakan rekaman komunikasi, termasuk kemampuan untuk mendokumentasikan (juga memodifikasi) proses komunikasi. Memori terolahkan komputer (computer processable memory) berarti bahwa informasi dapat diorganisir dan diatur secara elektronik, misalnya dapat diperoleh melalui proses pencarian. Dan konkurensi (concurreny) merupakan kemampuan media untuk memfasilitasi interaksi antara banyak pengguna secara simultan (Harmoni, 2010). 


\section{Media Richness Theory (MRT) dan Kepercayaan}

Kepercayaan merupakan suatu pilar utama dari teori media richness. Akar dari teori media richness adalah penegasan antara ambiguitas dan media komunikasi. Menurut Jarvenpaa and Leidner (1999) dalam Cho et al. (2009) menyatakan bahwa "media komunikasi di dalam komputer dapat menghilangkan jenis isyarat komunikasi yang sering orang pergunakan dalam menyampaikan kepercayaan”, peneliti juga berharap pengguna jaringan elektronik untuk tetap mengembangkan kepercayaan yang tinggi. Secara khusus, penggunaan media yang kaya menyebabkan pengguna untuk dapat mengembangkan tingkat kepercayaan atau kredibilitas pada pihak lain dalam pengkomunikasian. Burgoon et al. (2002) berteori bahwa: Leaner modality formats, by producing a limited cues environment, may reduce not only the total amount of information available upon which people rely to form credibility and other social judgments but may decrease redundant and complementary information that contributes to mutual understanding.

Oleh karena itu, media yang kaya dapat menyebabkan penilaian sosial yang lebih positif dan tingkat kepercayaan yang lebih tinggi dari pengguna pelaporan CSR. Dari hasil penelitian Burgoon et al. (2002) dalam Cho et al. (2009) dengan mengoperasionalkan "kredibilitas" yang terdiri dari kedua kepercayaan dan kompetensi, dan menunjukkan bahwa kekayaan media komunikasi secara positif terkait dengan tingkat kepercayaan.

Menurut Agarwal dan Venkatesh (2002) dalam Cho et al. (2009) berpendapat bahwa desain pada situs web perusahaan bukan tanpa resiko karena melibatkan emosi konsumen dan investor. Mereka juga menyatakan bahwa "kemampuan multimedia, kekayaan, dan interaktivitas lingkungan web (yaitu gaya situs web dan presentasi) memiliki potensi yang melibatkan pengguna dengan cara yang tidak dapat ditunjukkan oleh media lain”. Oleh karena itu perusahaan menyadari emosi tersebut dan mereka secara bijak akan mempertimbangkan aspek ini ketika mengungkapan informasi sosial dan lingkungan pada situs web mereka. Kepercayaan dianggap dari bagian emosi-emosi yang dijelaskan oleh Agarwal dan Venkatesh (2002) dalam Cho et al. (2009).

McKnight et al. (2002) menunjukkan bahwa membina kepercayaan dalam lingkungan online adalah penting bagi perusahaan karena membantu pengguna internet mengatasi persepsi mereka terhadap risiko dan ketidakamanan. Model kepercayaan dari McKnight et al. (2002) adalah membedakan antara keyakinan saling percaya dan niat saling percaya, yang dimana keyakinan saling percaya adalah keyakinan seseorang bahwa pihak lain memiliki kualitas yang menguntungkan, sedangkan niat percaya lebih mencerminkan kemauan individu untuk bergantung pada pihak lain.

\section{Sensitivitas Lingkungan Industri}

Menurut Munif (2010) sensitivitas industri telah diidentifikasikan sebagai faktor potensial yang mempengaruhi indeks praktik pengungkapan sosial perusahaan. Pada umumnya, perusahaan yang mempunyai tingkat sensitivitas industri yang tinggi merupakan perusahaan yang berhubungan langsung dengan konsumen dan kepentingan lainnya. Mahdiyah (2008) dalam Munif (2010) menggambarkan bahwa perusahaan yang berada pada industri yang mempunyai tingkat sensitivitas industri tinggi akan memperoleh perhatian dari masyarakat karena aktivitas operasi perusahaan memiliki potensi untuk berhubungan langsung dengan kepentingan luas. Dalam Reverte (2008) menyatakan bahwa “corporations 
from industries whose manufacturing process has a negative influence on the environment disclose and report considerably more information than corporations from other industries".

Menurut Zaleha (2005) dalam Munif (2010) perusahaan yang terklasifikasi dalam kelompok sensitivitas industri tinggi antara lain perusahaan perminyakan dan pertambangan, kertas, hutan, kimia, otomotif, agribisnis, tembakau dan rokok, penerbangan, produk makanan dan minuman, media dan komunikasi, energi (listrik), engineering, kesehatan serta transportasi dan pariwisata. Sedangkan kelompok sensitivitas industri rendah terdiri dari bangunan keuangan dan perbankan, pemasok peralatan medis, properti, retailer, tekstil dan produk tekstil, produk personal dan produk rumah tangga.

\section{Persepsi CSR}

Ada beberapa alasan mengapa perusahaan mengungkapan aktivitas sosialnya kepada stakeholder. Matthew (1995) dalam Hartanti (2008) mengklasifikasikan alasan ini menjadi tiga:

a. Adanya argumen yang menyatakan pengungkapan sosial memiliki dampak positif bagi kinerja organisasi.

b. Pengungkapan dapat melegitimasi perilaku organisasi dengan cara mempengaruhi persepsi dari stakeholder lain.

c. Pengungkapan sosial yang sukarela menunjukkan akuntabilitas moral perusahaan.

Menurut Hartanti (2008) menyatakan bahwa faktor persepsi yang ada terlihat bahwa faktor harapan, media pilihan untuk berinvestasi, keyakinan, reputasi, dan integritas adalah faktor-faktor yang mempengaruhi persepsi responden dalam bereaksi terhadap isu-isu CSR. Sementara format dan motivasi sama sekali tidak menjadi salah satu faktor yang membentuk persepsi responden dilihat dari aspek gender, usia, lama masa bekerja, dan juga stakeholder.

\section{Gambar 1. Model Penelitian}

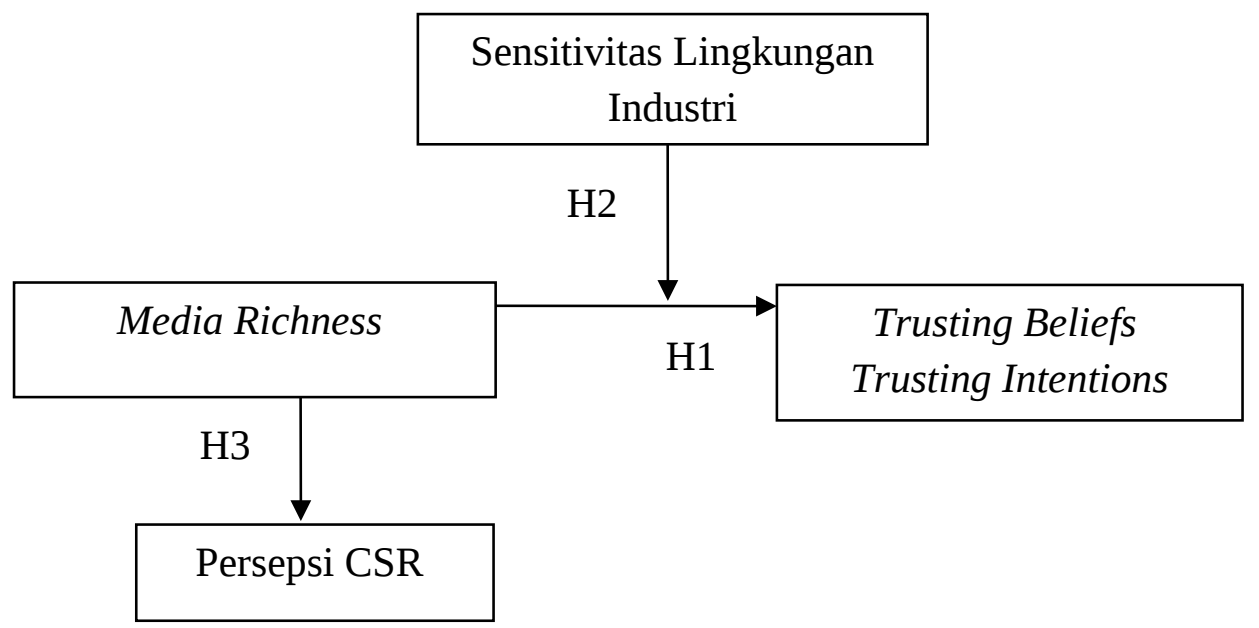

Sumber: Cho et al, 2009 


\section{Pengembangan Hipotesis}

\section{PengaruhMedia Richness terhadap Kepercayaan Stakeholder}

Pengungkapan multimedia secara visual merupakan tipe terkaya dalam pengungkapan media online (Palmer, 2002 dalam Cho et al, 2009). Pengungkapan yang hanya berisi teks dan gambar visual saja merupakan tingkat terendah dari kekayaan media. Karena dalam hirarki media richness jika hanya terdapat teks dalam pengungkapannya maka dapat dikatakan low richness sedangkan apabila dalam pengungkapannya terdapat pula gambar visual maka dapat dikatakan medium richness dan apabila dalam pengungkapannya terdapat video, gambar visual, dan teks maka dapat dikatakan high richness. Apabila laporan pengungkapan corporate social responsibility termasuk dalam high richness berarti perusahaan menggunakan dengan baik media richness yang dapat disajikan dalam pengungkapan corporate social responsibility di website resmi perusahaan.

Media richness menyebabkan penilaian sosial yang lebih positif seperti kepercayaan dan kompetensi (Burgoon et al, 2002 dalam Cho et al, 2009), yang diharapkan bagi para pengguna laporan corporate social responsibility dapat menunjukkan tingkat kepercayaannya apabila dalam pengungkapan corporate social responsibility menggunakan media richness nya dengan baik atau high richness dibandingkan dengan pengungkapan corporate social responsibility dengan media richness yang rendah atau low richness. Oleh karena itu dapat dihipotesiskan:

$H_{1}$ : Media richness dalam penyajian pengungkapan corporate social responsibility melalui media situs web berpengaruh positif terhadap tingkat kepercayaan stakeholder dalam pengungkapan corporate social responsibility.

\section{PengaruhMedia Richness terhadap Kepercayaan Stakeholder dengan Sensitivitas Lingkungan Industri sebagai pemoderasi.}

Sebelum membuat pelaporan pengungkapan lingkungan, perusahaan biasanya mengontrol dampak dari industri perusahaan (Patten, 2002 dalam Cho et al, 2009) atau memeriksa perusahaan yang hanya beroperasi di industri yang peka terhadap lingkungan (Cho et al, 2006 dalam Cho et al. 2009). Maksud dari hal tersebut adalah mengasumsikan bahwa organiasasi dalam industri yang sensitif atau peka terhadap lingkungan "terlibat dalam proses legitimasi” (Milne dan Patten, 2002) dan dapat membantu meringankan persepsi stakeholder yang berpotensi negatif terhadap organisasi karena kinerja lingkungan yang buruk. Karena industri yang sensitif pada umumnya memiliki masalah dengan lingkungan lebih besar dibandingkan dengan industri yang tidak langsung bersinggungan dengan lingkungan atau non industri. Dan perusahaan yang bersinggungan langsung dengan lingkungan atau yang mempunyai kepekaan lingkungan yang sensitif terkadang menyajikan pengungkapkan laporan corporate social responsibilitysecara berlebihan.

Maka dari itu, stakeholder dan pengguna laporan corporate social responsibility kemungkinan cenderung kurang mempercayai pengungkapan corporate social responsibility dari perusahaan-perusahaan yang bersinggungan langsung dengan kepekaan terhadap lingkungan dibandingkan dengan perusahaan non industri yang tidak langsung bersinggungan dengan kepekaan lingkungan yang sensitif. Oleh karena itu, dapat dihipotesiskan:

$\mathrm{H}_{2}$ : Sensitivitas lingkungan industri akan memoderasi hubungan antara media richness dalam penyajian pengungkapan corporate social responsibility melalui media situs web 
dengan tingkat kepercayaan stakeholder dalam pengungkapan corporate social responsibility.

\section{PengaruhMedia Richness dan Persepsi Corporate Social Responsibility}

Karena pengungkapan corporate social responsibility melalui website tampaknya akan digunakan sebagai alat legitimasi dalam mengimbangi tekanan negatif terhadap lingkungan sosial dan politik (Lodhia, 2004), dan penyajian pengungkapan corporate social responsibility mungkin hanya dirancang untuk secara positif mempengaruhi persepsi pengguna corporate social responsibility. Penyajian pengungkapan corporate social responsibility dengan memanfaatkan media richness dengan baik akan mempengaruhi persepsi pengguna corporate social responsibility. Jika kekayaan persentasi visual dapat membiaskan persepsi pengguna laporan corporate social responsibility, maka (Cho et al, 2009) mengantisipasi pengguna laporan corporate social responsibility untuk menilai tingkat tanggung jawab sosial yang lebih tinggi dengan menggunakan persentasi media richness pada website resmi perusahaan. Pengguna akan melihat pengungkapan corporate social responsibility dan menilai aktivitas perusahaan terhadap lingkungannya. Oleh karena itu, maka dapat dihipotesiskan:

$\mathrm{H}_{3}$ : Media richness dalam pengungkapan corporate social responsibility berpengaruh positif terhadap tingkat persepsi stakeholder dalam pengungkapan corporate social responsibility.

\section{Populasi dan Sampel Penelitian}

\section{METODE}

Populasi dalam penelitian ini adalah manajer pada perusahaan manufaktur di provinsi Banten yang listing di Bursa Efek Indonesia (BEI). Teknik penentuan sampel dalam penelitian ini dengan menggunakan teknik purposive sampling. Metode purposive samping merupakan metode pemilihan sampel yang seseuai dengan penelitian ini yaitu; 1) Perusahaan manufaktur di provinsi Banten yang listing di BEI, 2) Responden dalam penelitian ini adalah manajer keuangan, manajer produksi, manajer sumber daya manusia, manajer pemasaran.

\section{Jenis dan Prosedur Pengumpulan Data Penelitian}

Data yang digunakan pada penelitian ini dikumpulkan melalui survei dengan mengirim kuesioner kepada para manajer level menengah. Metode pengumpulan data dilakukan dengan kombinasi dua cara berikut; (1) melalui jasa pos, dan (2) secara langsung oleh peneliti. Kombinasi kedua metode tersebut dipilih dengan pertimbangan kemampuan peneliti dan dalam usaha meningkatkan tingkat pengembalian kuesioner.

\section{Variabel Penelitian dan Pengukurannya}

Variabel penelitian dan pengukuruan variabel penelitian dalam penelitian inidapat dilihat pada tabel 1 berikut ini:

\section{Tabel 1. Variabel Penelitian dan Pengukuran}




\begin{tabular}{|c|c|c|c|c|}
\hline Variabel & Pengertian & Indikator & Skala & Sumber \\
\hline Media Richness & Kegunaan suatu media & - Low Richness & Skala & Palmer (2002) \\
\hline Teori $\left(\mathrm{X}_{1}\right)$ & $\begin{array}{l}\text { ditentukan oleh "kekayaan”- } \\
\text { nya (richness). MRT ini } \\
\text { berkenaan dengan penentuan } \\
\text { media komunikasi yang } \\
\text { paling tepat untuk } \\
\text { menghadapi ketidakpastian } \\
\text { dan ketidakjelasan dari } \\
\text { informasi }\end{array}$ & $\begin{array}{l}\text { - Medium Richness } \\
\text { - High Richness }\end{array}$ & Nominal & $\begin{array}{l}\text { dan Cho et al, } \\
\text { (2009) }\end{array}$ \\
\hline $\begin{array}{l}\text { Keyakinan } \\
\text { saling percaya } \\
\text { dan Niat saling } \\
\text { percaya }\left(\mathrm{Y}_{1}\right)\end{array}$ & $\begin{array}{l}\text { Membina kepercayaan dalam } \\
\text { lingkungan online adalah } \\
\text { penting bagi perusahaan } \\
\text { karena membantu pengguna } \\
\text { internet mengatasi persepsi } \\
\text { mereka terhadap risiko dan } \\
\text { ketidakamanan. }\end{array}$ & $\begin{array}{l}\text { - Truthful } \\
\text { - Honest } \\
\text { - Commitments } \\
\text { - Sincere and Genuine } \\
\text { - Comfortable } \\
\text { - Trust } \\
\text { - Count Information } \\
\text { - Rely Information }\end{array}$ & $\begin{array}{l}\text { Poin } 5 \text { skala } \\
\text { likert }\end{array}$ & $\begin{array}{l}\text { McKnight et al, } \\
2002 \text { dan Cho et } \\
\text { al, } 2009\end{array}$ \\
\hline $\begin{array}{l}\text { Persepsi } \\
\text { Tanggung Jawab } \\
\text { Sosial dan } \\
\text { Lingkungan }\left(\mathrm{Y}_{2}\right)\end{array}$ & $\begin{array}{l}\text { Sebuah proses saat individu } \\
\text { mengatur dan } \\
\text { menginterprestasikan kesan- } \\
\text { kesan sensoris mereka guna } \\
\text { memberikan arti bagi } \\
\text { lingkungan mereka. }\end{array}$ & $\begin{array}{l}\text { - Motivasi } \\
\text { - Format } \\
\text { - Harapan } \\
\text { - Keyakinan } \\
\text { - Integritas }\end{array}$ & $\begin{array}{l}\text { Poin } 5 \text { skala } \\
\text { likert }\end{array}$ & $\begin{array}{l}\text { Hartanti et al, } \\
2008\end{array}$ \\
\hline $\begin{array}{l}\text { Sensitivitas } \\
\text { Industri } \\
\text { Lingkungan } \\
\text { (Moderating) }\end{array}$ & $\begin{array}{l}\text { Sensitivitas industri telah } \\
\text { diidentifikasikan sebagai } \\
\text { faktor potensial yang } \\
\text { mempengaruhi indeks praktik } \\
\text { pengungkapan sosial } \\
\text { perusahaan. Pada umumnya, } \\
\text { perusahaan yang mempunyai } \\
\text { tingkat sensitivitas industri } \\
\text { yang tinggi merupakan } \\
\text { perusahaan yang } \\
\text { berhubungan langsung } \\
\text { dengan konsumen dan } \\
\text { kepentingan lainnya. }\end{array}$ & $\begin{array}{l}\text { - } 0 \text { untuk perusahaan } \\
\text { dengan sensitivitas } \\
\text { rendah } \\
\text { - } 1 \text { untuk perusahaan } \\
\text { dengan sensitivitas } \\
\text { tinggi }\end{array}$ & Nominal & Munif et al, 2010 \\
\hline
\end{tabular}

Sumber : Diolah dari berbagai sumber (2018)

\section{Metode Analisis Data}

Metode analisis data yang dipergunakan dalam penelitian ini meliputi : Uji validitas dan reliabelitas data, uji asumsi klasik, uji regresi sederhana, dan uji selisih nilai mutlak.

\section{Pengujian Hipotesis}

\section{Model Regresi Linier Sederhana.}

Analisis ini digunakan untuk menguji pengaruh satu variabel independen terhadap variabel dependen (Santoso, 2000). Analisis ini digunakan untuk menguji pengaruh media 
richness dalam penyajian pengungkapan corporate social responsibility terhadap persepsi corporate social responsibility (hipotesis 3 ).

$\mathrm{Y}=\beta 0+\beta 1 \mathrm{X} 1+\mathrm{e}(3)$

\section{Uji Nilai Selisih Mutlak}

Menurut Frucot and Shearon (1991) dalam Ghozali (2016) mengajukan model regresi yang agak berbeda untuk menguji pengaruh moderasi yaitu dengan model nilai selisih mutlak dari variabel independen dengan rumus persamaan regresi:

$\mathrm{Y}=\mathrm{a}+\mathrm{b} 1 \mathrm{X} 1+\mathrm{b} 2+\mathrm{b} 3 \mathrm{XX} 1-\mathrm{X} 2 \mathrm{c}$

Dimana:

$\mathrm{Xi}=$ merupakan nilai standardized score $[(\mathrm{Xi}-\overline{\mathrm{X}}) / \sigma \mathrm{X}]$

$\square \mathrm{X} 1$ - X2 $\square=$ merupakan interaksi yang diukur dengan nilai absolut perbedaan antara X1 dan $\mathrm{X} 2$

Menurut Frucot and Shearon (1991) dalam Ghozali (2016) interaksi seperti ini lebih disukai oleh karena ekspetasi sebelumnya berhubungan dengan kombinasi antara X1 dan X2 dan berpengaruh terhadap Y. Oleh karena itu rumus regresi yang digunakan dalam pengujian penelitian ini adalah :

TRUST = a + b1 MRT + b2 SEN + b3 [MRT - SEN 1

Dimana nilai MRT dan SEN adalah standardized.

\section{Statistik Deskriptif Variabel Penelitian}

Data yang diperoleh dalam penelitian ini dikumpulkan dengan menyebarkan kuesioner kepada responden yaitu manajer (manajer keuangan, manajer produksi, manajer sumber daya manusia, manajer pemasaran) pada perusahaan manufaktur di provinsi Banten yang listing di Bursa Efek Indonesia (BEI). Kuesioner yang disebarkan sejumlah 180 kuesioner. Kalkulasi antara jumlah kuesioner yang dibagikan dengan yang berhasil dikumpulkan terdapat pada tabel 2 berikut ini :

Tabel 2. Daftar Kuesioner

\begin{tabular}{lcc}
\hline Kuesioner & Jumlah & Persentase \\
\hline Kuesioner yang didistribusikan & 180 & $100 \%$ \\
Kuesioner yang tidak kembali & $(104)$ & $58 \%$ \\
Kuesioner yang tidak diisi lengkap & $(9)$ & $5 \%$ \\
Tingkat pengembalian (respon rate) & 76 & $42 \%$ \\
Tingkat pengembalian yang bisa digunakan & 67 & $37 \%$ \\
\hline
\end{tabular}

Sumber : Data diolah, 2018

Dari jumlah kuesioner yang dibagikan, kuesioner yang diisi dan dikembalikan adalah 76 kuesioner dengan tingkat respon rate sebesar 42\%. Jumlah kuesioner yang dikembalikan tapi tidak diisi dengan lengkap sejumlah 9 kuesioner. Oleh karena itu, jumlah data yang dapat diolah untuk analisis dalam penelitian ini adalah sejumlah 67 kuesioner. 


\section{Analisis Data}

\section{Uji Validitas (Validity Test)}

Uji validitas dilakukan untuk mengukur sah atau valid tidaknya suatu indikator yang berbentuk kuesioner. Pengujian validitas variabel user trust dan persepsi corporate social responsibility. Berdasarkan hasil perhitungan uji validitas dapat diketahui bahwa indikatorindikator pertanyaan dari variabel user trust dan persepsi corporate social responsibility yang diajukan terhadap responden valid.

\section{Uji Reliabilitas (Reliability Test)}

Penelitian ini melakukan uji reliabilitas dengan menghitung cronbach alpha dari masing-masing instrumen dalam satu variabel. Instrumen yang digunakan dalam variabel tersebut dikatakan andal reliable) apabila memiliki cronbach alpha ${ }^{\geq} 0,60$.

Tabel 4. Pengujian Reliabilitas Variabel User Trust Reliability Statistics

\begin{tabular}{rrrr}
\hline Cronbach's Alpha & $\begin{array}{c}\text { Cronbach's Alpha Based } \\
\text { on Standardized Items }\end{array}$ & N of Items & \\
\hline, 882 &, 886 & 31 \\
\hline
\end{tabular}

Sumber : Output SPSS yang diolah, 2018

Berdasarkan hasil perhitungan yang ditunjukkan pada tabel diatas nilai Cronbach's Alpha sebesar 0,773>0,60 sehingga dapat disimpulkan bahwa butir-butir pertanyaan pada variabel Y1 dinyatakan reliable (andal).

Tabel 5. Uji Reliabilitas Persepsi Corporate Social Responsibility Reliability Statistics

\begin{tabular}{ccc}
\hline Cronbach's Alpha & $\begin{array}{c}\text { Cronbach's Alpha Based } \\
\text { on Standardized Items }\end{array}$ & N of Items \\
& & \\
\hline ,776 &, 773 & 9 \\
\hline
\end{tabular}

Sumber : Output SPSS yang diolah, 2018

Berdasarkan hasil perhitungan yang ditunjukkan pada tabel diatas nilai Cronbach's Alpha sebesar 0,886>0,60 sehingga dapat disimpulkan bahwa butir-butir pertanyaan pada variabel Y2 dinyatakan reliable (andal).

\section{Statistik Deskripstif}

Berdasarkan data pada tabel statistik deskriptif dapat diketahui nilai rata-rata dan standar deviasi.

Tabel 6. Statistik Deskriptif

Descriptive Statistics

\begin{tabular}{lrrrrr}
\hline & N & \multicolumn{1}{c}{ Minimum } & \multicolumn{1}{c}{ Maximum } & \multicolumn{1}{c}{ Mean } & Std. Deviation \\
\hline Media & 67 & 1 & 3 & 2,08 &, 517 \\
UT & 67 & 31 & 45 & 38,12 & 3,142 \\
PRSP & 67 & 103 & 150 & 128,27 & 9,687 \\
Valid N (listwise) & 67 & & & & \\
\hline
\end{tabular}

Sumber : Output SPSS yang diolah, 2018 
Berdasarkan data yang terdapat pada tabel 6 menunjukkan bahwa pada variabel media, jawaban dari 67 responden menunjukkan jawaban terendah (minimum) adalah sebanyak 1 dan jawaban tertinggi (maksimum) adalah sebanyak 3. Rata-rata hasil jawaban responden adalah 2,08 dengan standar deviasi 0,517. Untuk variabel user trust jawaban dari 67 responden menunjukkan jawaban terendah adalah 31 dan jawaban tertinggi adalah sebanyak 45. Rata-rata hasil jawaban responden adalah 38,12 dengan standar deviasi 3,142. Untuk variabel persepsi corporate social responsibility jawaban dari 67 responden menunujukkan jawaban terendah adalah sebanyak 103 dan jawaban tertinggi adalah sebanyak 150. Rata-rata hasil jawaban responden adalah 128,27 dengan standar deviasi 9,687.

Tabel 7. Hasil Statistik Deskriptif Variabel Dummy Descriptive Statistics

\begin{tabular}{lrrrrr}
\hline & $\mathrm{N}$ & Minimum & Maximum & Sum & Mean \\
\hline SEN & 67 & 0 & 1 & 37 &, 57 \\
Valid N & & & & & \\
(listwise) & 67 & & & & \\
\hline
\end{tabular}

Sumber: Output SPSS yang diolah, 2018

Berdasarkan data diatas menunjukkan bahwa terdapat 67 perusahaan dengan sensitivitas industri 1 atau sensitivitas industri tinggi dan terdapat 30 perusahaan dengan sensitivitas industri 0 atau sensitivitas industri rendah. Tabel diatas juga menunjukkan bahwa rata-rata perusahaan dengan sensitivitas industri tinggi dari 67 perusahaan dengan adalah 0,57 .

\section{Uji Asumsi Klasik \\ Multikolonieritas}

Dari hasil output di atas, perhitungan nilai Tolerance menunjukkan tidak ada variabel independen yang memiliki nilai Tolerance kurang dari 0,10 yang berarti tidak ada korelasi antar variabel independen yang nilainya lebih dari 95\%. Dan nilai VIF juga menunjukkan bahwa tidak ada variabel independen yang memiliki nilai VIF lebih dari 10. Jadi dapat disimpulkan bahwa tidak ada multikolonieritas antar variabel independen dalam model regresi.

\section{Heteroskedastisitas}


Adapun hasil dari uji heteroskedastisitas dari penelitian ini dapat dilihat sebagai berikut:

Tabel 8.Hasil Uji Heteroskedastisitas - Uji Glejser

Coefficients $^{\mathrm{a}}$

\begin{tabular}{|c|c|c|c|c|c|}
\hline \multirow[t]{2}{*}{ Model } & \multicolumn{2}{|c|}{$\begin{array}{l}\text { Unstandardized } \\
\text { Coefficients }\end{array}$} & $\begin{array}{l}\text { Standardized } \\
\text { Coefficients }\end{array}$ & $\mathrm{t}$ & Sig. \\
\hline & B & Std. Error & Beta & & \\
\hline (Constant) & 2,265 & 1,023 & & 2,214 & 031 \\
\hline 1Media & ,037 & ,461 & ,011 & ,081 & 936 \\
\hline SEN &,- 079 & ,478 &,- 023 &,- 166 & ,869 \\
\hline
\end{tabular}

a. Dependent Variable: ABS_RES1

Sumber: Output SPSS yang diolah, 2018

Hasil uji heteroskedastisitas pada model dengan uji glejser menunjukkan bahwa tidak ada variabel independen yang signifikan secara statistik mempengaruhi variabel dependen nilai Absolut Res_1 (abs_res1). Hal ini terlihat dari probabilitas signifikansinya diatas tingkat kepercayaan 5\%. Jadi dapat disimpulkan model regresi tidak mengandung adanya heteroskedastisitas.

\section{Normalitas}

Adapun hasil dari kolmogorov-smirnov untuk uji normalitas data adalah sebagai berikut:

Tabel 9. Uji Normalitas

One-Sample Kolmogorov-Smirnov Test

\begin{tabular}{llr}
\hline & & Unstandardized Residual \\
\hline $\mathrm{N}$ & & 67 \\
Normal Parameters ${ }^{\mathrm{a}, \mathrm{b}}$ & Mean & 2,43 \\
& Std. Deviation & 2,90148594 \\
& Absolute &, 084 \\
Most Extreme Differences & Positive &, 057 \\
& Negative &,- 084 \\
Kolmogorov-Smirnov Z & &, 630 \\
Asymp. Sig. (2-tailed) & &, 823 \\
\hline a. Test distribution is Normal. & \\
b. Calculated from data. &
\end{tabular}

Sumber : Output SPSS yang diolah, 2018

Dari tabel di atas Kolmogorov-Smirnov Test menunjukkan nilai signifikasi lebih besar dari 0,05 yaitu sebesar 0,823. Maka data residual terdistribusi normal. 


\section{Uji Hipotesis}

Pengujian terhadap hipotesis yang dilakukan dalam penelitian ini sebagai berikut:

\section{Tabel 10 Hasil Pengujian Hipotesis \\ Coefficients $^{\mathrm{a}}$}

\begin{tabular}{rlrrrrr}
\hline Model & & Unstandardized Coefficients & $\begin{array}{c}\text { Standardized } \\
\text { Coefficients } \\
\text { Beta }\end{array}$ & t & Sig. \\
& & \multicolumn{1}{c}{ B } & Std. Error & B & \\
\hline \multirow{2}{*}{1} & (Constant) & 33,911 & 1,813 & & 18,702 &, 000 \\
& Media & 2,306 &, 767 &, 382 & 3,009 &, 004 \\
& Moderating &, 293 &, 582 &, 064 &, 503 &, 617 \\
\hline
\end{tabular}

a. Dependent Variable: UT

\section{Coefficients $^{\mathbf{a}}$}

\begin{tabular}{|c|c|c|c|c|c|c|}
\hline \multirow[t]{2}{*}{ Model } & & \multicolumn{2}{|c|}{ Unstandardized Coefficients } & \multirow{2}{*}{$\begin{array}{c}\text { Standardized } \\
\text { Coefficients } \\
\text { Beta }\end{array}$} & \multirow[t]{2}{*}{$\mathrm{t}$} & \multirow[t]{2}{*}{ Sig. } \\
\hline & & B & Std. Error & & & \\
\hline \multirow{2}{*}{1} & (Constant) & 116,465 & 5,323 & & 21,878 & ,000 \\
\hline & Media & 4,696 & 2,514 & ,246 & 1,867 & ,067 \\
\hline
\end{tabular}

Sumber : Output SPSS yang diolah, 2018

Berdasarkan tabel diatas maka diperoleh persamaan regresi sebagai berikut:

$$
\begin{aligned}
& U T=33,911+2,306 \text { Media }+ \text { 0,293 } \square \text { Media }- \text { SEN } \square \\
& P R S P=116,465-4,696 \text { Media }
\end{aligned}
$$

\section{Uji Hipotesis Pertama}

Hasil penelitian menunjukkan nilai $\beta_{1}$ sebesar 2,306 dengan tingkat signifikansi sebesar 0,004 berada lebih rendah pada $\alpha=0,05$, sehingga hipotesis pertama diterima. Berarti dapat disimpulkan bahwa media richness dalam penyajian pengungkapan corporate social responsibility melalui media situs web berpengaruh positif terhadap tingkat kepercayaan stakeholder dalam pengungkapan corporate social responsibility.

\section{Uji Hipotesis Kedua}

Hasil penelitian menunjukkan nilai $\beta_{1}$ sebesar 0,293 dengan tingkat signifikansi sebesar 0,617 berada lebih tinggi pada $\alpha=0,05$, sehingga hipotesis kedua ditolak. Berarti dapat disimpulkan bahwa sensitivitas lingkungan industri tidak memoderasi hubungan antaramedia richnessdengan tingkat kepercayaan stakeholder namun tidak signifikan.

\section{Uji Hipotesis Ketiga}

Hasil penelitian menunjukkan nilai $\beta_{1}$ sebesar 4,696 dengan tingkat signifikansi sebesar 0,067 berada lebih tinggi pada $\alpha=0,05$, sehingga hipotesis ketiga ditolak. Berarti dapat disimpulkan bahwa media richness dalam pengungkapan corporate social responsibilityberpengaruh positif terhadap tingkat persepsi stakeholder dalam pengungkapan corporate social responsibility namun tidak signifikan. 


\section{Pembahasan Hipotesis}

\section{Pengaruh Media Richness terhadap Tingkat Kepercayaan Stakehoder}

Berdasarkan pengolahan data yang diperoleh bahwa media richness memiliki pengaruh positif terhadap tingkat kepercayaan stakeholder yang ditunjukkan dengan nilai signifikan 0,004 lebih kecil dari taraf signifikansi 5\%, yang menandakan bahwa hipotesis diterima.

Berdasarkan teori yang dikemukakan oleh Burgoon et al. (2002) bahwa dengan memproduksi lingkungan isyarat yang terbatas dapat mengurangi jumlah informasi yang tersedia dimana orang mengandalkan untuk membentuk penilaian sosial, tetapi dapat menunrunkan informasi yang berlebihan agar dapat lebih dimengerti. Begitupula dengan teori keprcayaan yang dikemukakan oleh McKnight et al. (2002) bahwa trusting beliefs merupakan keyakinan individu bahwa pihak lain memiliki kualitas yang menguntungkan, sedangkan trusting intentions merupakan keinginan individu untuk bergantung pada pihak lain. Jadi berdasarkan teori tersebut dapat dinyatakan bahwa media richness akan berhubungan positif dengan tingkat kepercayaan stakeholder. Para stakeholder lebih bersedia untuk bergantung pada perusahaan dan terlibat dalam perilaku yang berhubungan dengan kepercayaan pada perusahaan yang situs web pengungkapannya menggunakan media richness yang tinggi.

Hasil ini konsisten dengan temuan yang dilakukan oleh Cho et al. (2009) yang menyatakan bahwa kekayaan media atau keunggulan media yang tinggi akan membuat penilaian terhadap penyajian laporan corporate social responsibility lebih positif dan tingkat kepercayaan para pengguna laporan corporate social responsibility menjadi lebih tinggi. Penyajian laporan corporate social responsibility dengan menggunakan keunggulan media yang tinggi (penggunaan video) dapat menumbuhkan rasa kepercayaan yang positif dari pengguna laporan terhadap perusahaan. Karena pengguna laporan akan merasa lebih aman dan lebih percaya dalam melakukan transaksi dengan perusahaan yang transparan dalam penyajian laporan corporate social responsibilitynya.

\section{Pengaruh Media Richness terhadap Tingkat Kepercayaan dengan Sensitivitas Lingkungan Industri sebagai pemoderasi.}

.Bahwa variabel sensitivitas lingkungan industri sebagai pemoderasi memiliki hubungan positif dengan tingkat signifikansi 0,617 jauh diatas 0,005 yang menyatakan bahwa hipotesis kedua ditolak. Jadi dari hasil tersebut dapat disimpulkan bahwa sensitivitas lingkungan industri tidak memoderasi hubungan antara media richness dengan tingkat kepercayaan.

Dalam Reverte (2008) menyatakan bahwa bahwa perusahaan manufaktur atau perusahaan yang langsung berhubungan dengan lingkungan memiliki pengaruh negatif dalam pengungkapanan laporan lingkungan dibandingkan dengan perusahaan yang tidak secara langsung berhubungan dengan lingkungan. Jadi dapat dinyatakan bahwa sensitivitas lingkungan industri tidak memoderasi hubungan positif antara media richness dengan tingkat kepercayaan stakeholder.

Hal ini konsisten dengan penelitian yang dilakukan oleh Cho et al. (2009) yang menyatakan bahwa sensitivitas lingkungan industri tidak memoderasi hubungan media richness dengan tingkat kepercayaan. Karena kepercayaan pengguna akan menurun pada 
perusahaan dengan sensitivitas lingkungan industri tinggi (perusahaan yang berhubungan langsung dengan lingkungan) dibandingkan dengan perusahaan dengan sensitivitas lingkungan industri yang rendah (perusaahaan yang tidak secara langsung berhubungan dengan lingkungan). Pada saat perusahaan dengan sensitivitas lingkungan industri tinggi menggunakan keunggulan media (video) dalam menyajiakan laporan corporate social responsibilitynya, terkadang hal tersebut dapat membiaskan sehingga dapat menurunkan tingkat kepercayaan terhadap perusahaan tersebut.

\section{PengaruhMedia Richness terhadap Persepsi Corporate Social Responsibility}

Bahwa media richness memiliki hubungan positif terhadap persepsi corporate social responsibility dengan tingkat signifikansi 0,067 jauh diatas 0,005 yang menyatakan bahwa hipotesis ketiga ditolak. Jadi dari hasil tersebut dapat disimpulkan bahwa media richness tidak memiliki pengaruh positif terhadap persepsi corporate social responsibility.

Hal ini dapat diartikan keunggulan media atau kekayaan media dalam penyajian laporan corporate social responsibility bukanlah hal yang berpengaruh besar dalam pembentukan persepsi laporan corporate social responsibility karena keunggulan media juga dapat membiaskan persepsi corporate social responsibility. Hal ini dapat dilihat dari semakin tinggi penyajian pengungkapan corporate social responsibility (dengan menggunakan keunggulan media) dapat membuat persepsi stakeholder terhadap penyajian corporate social responsibility perusahaan menjadi baik dan tidak baik. Jadinya dalam pembentukan persepsi diperlukan hal lain yang dapat mendukung agar persepsi yang dapat timbul merupakan persepsi corporate social responsibility yang baik. Dan hal ini juga dibenarkan dengan penelitian yang dilakukan oleh Hartanti (2008) yang menyatakan bahwa reputasi perusahaan, isu strategis dan masalah integritas merupakan hal penting dalam pembentukan persepsi corporate social responsibility.

\section{Simpulan}

\section{SIMPULAN}

Berdasarkan analisis dan pembahasan pada bagian sebelumnya, maka dapat ditarik kesimpulan sebagai berikut: Hasil uji hipotesis pertama menunjukkan bahwa adanya pengaruh positif antara media richness terhadap user trust, yangberarti bahwa hipotesis pertama diterima. Hasil uji hipotesis kedua menunjukkan bahwa sensivitas lingkungan industritidak memoderasi hubungan antara media richness denganuser trust,yang berarti bahwa hipotesis kedua ditolak.Hasil uji hipotesis ketiga menunjukkan bahwa terdapatpengaruh positif namun tidak signifikan media richness terhadap persespi corporate social responsibility, yang berarti bahwa hipotesis ketiga ditolak. Keterbatasan dalam penelitian ini adalah pertama, jumlah responden yang relatif sedikit sehingga dapat menyebabkan hasil penelitian kurang maksimal dan kurang mewakili jumlah gambaran responden secara keseluruhan. Kedua, penelitian ini hanya terbatas pada responden yang lebih sering mengakses webite perusahaan. Media ini pada umumnya hanya di akses oleh pihak-pihak tertentu saja. Penelitian lebih lanjut diharapkan dapat mengarah pada penyempurnaan dari variabel yang digunakan dalam penelitian ini dan dapat mengembangkan penelitian terkait hubungan media richness terhadap user trust dan persepsi 
corporate social responsibility dengan sensitivitas lingkungan industri sebagai variabel moderating. Penelitian selanjutnya dapat menguji apakah terdapat hubungan media richness terkait persepsi corporate social responsibility dengan menggunakan pengukuran diluar website perusahaan. Hal ini dapat menambah literatur penelitian selanjutnya di Indonesia. Hasil dari penelitian ini diharapkan dapat memberikan pemahaman kepada para pengguna laporan corporate social responsibility baik melalui website perusahaan ataupun diluar website perusahaan. Selain itu dalam penelitian ini juga diharapkan dapat memberikan kontribusi bagi perusahaan yang menggunakan website resmi perusahaan sebagai salah satu media dalam menyajikan laporan corporate social responsibilitynya agar dapat memperhatikan penggunaan medianya supaya tidak membiaskan dari pengguna laporan corporate social responsibilitynya. Serta penelitian ini juga diharapkan dapat menambah wawasan bagi manajer.

\section{DAFTAR PUSTAKA}

Ardianto, Elvinaro Dr., Machfudz, Dindin M Drs., (2011). Efek Kedermawanan Pebisnis dan CSR. Jakarta: PT Gramedia

Burgoon, J.K., Bonito, J.A., Ramirez, A., Dunbar, N.E., Kam, K. and Fischer, J. (2002), "Testing theinteractivity principle: effects of mediation, propinquity, and verbal and nonverbal modalities in interpersonal interaction”, Journal of Communication, Vol. 52 No. 3,pp. 657-77.

Cho, C.H., Philips, J.R., Hageman, A.M., Patten, D.M., (2009), "Media Richness, User Trust, and Perceptions of Corporate Social Responsibility : an experimental investigation of visual web site disclosure”, Accounting, Auditing, \& Accountability Journal, Vol.22 No.6, pp. 933-952.

Daft, RL., and Lengel, R.H. (1986), "Organizational information requirements, media richness and structural design”, Management Science, Vol. 32 No. 5, pp. 554-71.

Deegan, J. (2002), "Introduction: The legitimising effect of social and environmental disclosure - a theoretical foundation”, Accounting, Auditing, \& Accountability Journal, Vol.15 No.3, pp. 282-311.

Ghozali, Imam. 2007. Aplikasi Analisis Multivariate dengan Program SPSS. Cetakan IV. Semarang: Badan Penerbit Universitas Diponegoro.

Harmoni, Ati., (2010), "Media Richness Theory dan Potensi Web sebagai Media Komunikasi CSR oleh Perusahaan”, In press.

Hartanti, Dwi., Rosantina, Elvia., Djakman, Chaerul., Sulistyorini, Dwi., Sari, Dahlia., (2008), "Perceptions On Corporate Social and Environmental Reporting: A Study In Capturing Public Confidence”, In press.

Hartanti, Dwi., Rahmawani., (2010), "Pengaruh Budaya dan Sosial Politik Terhadap Tampilan Situs Laporan Pertanggungjawaban Sosial Perusahaan: Studi Perbandingan Perusahaan Migas Indonesia dan Perusahaan Migas Amerika Serikat”. SNA XIII, Purwokerto. 
Lodhia, S.K. (2004), "Legitimacy motives for World Wide Web (WWW) environmental reporting: an exploratory study into present practices in the Australian minerals industry”, Journal of Accounting and Finance, Vol. 4, pp. 1-16.

McKnight, D.H., Choudhury, V. and Kacmar, C. (2002), "Developing and validiting trust measures for e-commerce: an integrative typology”, Information System Research, Vol. 13 No. 3, pp. 334-59.

Milne, MJ. and Patten, D.M. (2002), "Securing organizational legitimacy: an experimental decision case examining the impact of environmental disclosure", Accounting, Auditing \& Accountability Journal, Vol. 15 No. 3, pp. 372-405.

Munif, Aulia Zahra and Prabowo, Tri Jatmiko Wahyu., (2010), “ Faktor-faktor yang Mempengaruhi Indeks Pengungkapan Corporate Social Responsibility di Indonesia (Studi Empiris pada Perusahaan Non Keuangan yang Listing di BEI)”, Skripsi UNDIP.

Palmer, J.W. (2002), "Web site usability, design, and performance metrics”, Information Systems Research, Vol. 13 No. 2, pp.151-67.

Primadini, Intan., (2008), “Pengaruh persepsi khalayak mengenai CSR yang dipengaruhi oleh tingkat kredibilitas advertorial dan citra merek”, Skripsi FISIP UI.

Reverte, C. (2008). "Determinants of Corporate Social Responsibility Disclosure Ratings by Spanish Listed Firms”, Journal of Business Ethics (2009) 88:351-366 DOI 10.1007/s10551-008-9968-9.

Sembiring, Eddy Rismanda., (2005), “Karakteristik Perusahaan Dan Pengungkapan Tanggung Jawab Sosial: Study Empiris Pada Perusahaan Yang Tercatat Di Bursa Efek Jakarta”, SNA VIII, Solo.

Sugiyono. 2008. Metode Penelitian Kuantitatif Kualitatif dan R\&D. Bandung: Alfabeta. 